\title{
Effect of Acid- and Ultraviolet/Ozonolysis-Treated MWCNTs on the Electrical and Mechanical Properties of Epoxy Nanocomposites as Bipolar Plate Applications
}

\author{
Nishata Royan Rajendran Royan,, ${ }^{1,2}$ Abu Bakar Sulong, ${ }^{1,2}$ \\ Jaafar Sahari, 1,2 and Hendra Suherman ${ }^{1,3}$ \\ ${ }^{1}$ Fuel Cell Institute, Universiti Kebangsaan Malaysia, 43600 Bangi, Selangor, Malaysia \\ ${ }^{2}$ Department of Mechanical and Materials Engineering, Universiti Kebangsaan Malaysia, 43600 Bangi, Selangor, Malaysia \\ ${ }^{3}$ Department of Mechanical Engineering, Universitas Bung Hatta, 25143 Padang, West Sumatera, Indonesia \\ Correspondence should be addressed to Abu Bakar Sulong; abubakar@eng.ukm.my
}

Received 11 October 2012; Revised 19 December 2012; Accepted 16 January 2013

Academic Editor: Xu Hou

Copyright ( 2013 Nishata Royan Rajendran Royan et al. This is an open access article distributed under the Creative Commons Attribution License, which permits unrestricted use, distribution, and reproduction in any medium, provided the original work is properly cited.

\begin{abstract}
Carbon nanotubes (CNTs) have a huge potential as conductive fillers in conductive polymer composites (CPCs), particularly for bipolar plate applications. These composites are prepared using singlefiller and multifiller reinforced multiwalled carbon nanotubes (MWCNTs) that have undergone a chemical functionalization process. The electrical conductivity and mechanical properties of these composites are determined and compared between the different functionalization processes. The results show that $\mathrm{UV}^{-\mathrm{O}_{3}-}$ treated functionalization is capable of introducing carboxylic functional groups on CNTs. Acid-treated CNT composites give low electrical conductivity, compared with $\mathrm{UV} / \mathrm{O}_{3}$-treated and As-produced CNTs. The in- and through-plane electrical conductivities and flexural strength of multifiller EP/G/MWCNTs (As-produced and UV/O ${ }_{3}$-treated) achieved the US Department of Energy targets. Acid-treated CNT composites affect the electrical conductivity and mechanical properties of the nanocomposites. These data indicate that the nanocomposites developed in this work may be alternative attributers of bipolar plate requirements.
\end{abstract}

\section{Introduction}

Bipolar plates are the key components in a proton exchange membrane fuel cell (PEMFC) and perform as current conductors between cells, provide conduits for reactant gases flow, and constitute the backbone of a power stack [1]. Conventional pure graphite $(\mathrm{G})$ bipolar plates contribute significantly to the cost and weight of PEMFC stacks. Metals, such as stainless steel and metal alloys, are not preferable because of corrosion-related issues $[1,2]$. The development of lightweight, low-cost, and highly conductive polymer composite bipolar plates with a scope for mass production can aid the rapid commercialization of PEM fuel cells [35]. Therefore, polymer composite bipolar plates can replace heavier $\mathrm{G}$ bipolar plates in next-generation PEMFCs [6]. The materials chosen in the fabrication of bipolar plates have caught the attention of many researchers. One of the branches being studied is the polymer nanocomposite-based type. The reinforcing and/or electrically conducting fillers commonly used, including G, carbon fiber, and carbon black, have been reported to enhance the overall performance of composite plates formed using the conventional polymer processing technique [7-13]. Since the discovery of carbon nanotubes and their exceptional mechanical properties by Ijima, the idea of using them as reinforcing fibers in composite materials has been the driving force in composite design [14]. Theoretical and experimental results show the superior electrical properties of CNTs. Multiwalled carbon nanotubes (MWCNTs) are reported to be always electrically conductive and to have an electrical conductivity of approximately $1.85 \times$ $10^{3} \mathrm{~S} \mathrm{~cm}^{-1}$ [15]. Despite the MWCNTs' wide range of potential applications, their use often remains problematic because 
of the agglomeration caused by strong intertube van der Waals forces and their high surface energy due to the strong curvature of the thin nanotubes [16]. The functionalization of CNTs involves the generation of chemical moieties on their surface, which could improve solubility and process ability. These attributes allow CNTs to be combined with other types of materials, particularly polymer matrix [17]. Oxidation is the most common method of purifying CNTs via reflux in a concentrated acidic solution. The introduction of active functional groups, damage to the CNTs, and opening of caps may also be induced by oxidation. The extent of each of these effects depends on the oxidation conditions and has much influence on the physical and electrical properties of the composites $[18,19]$. The oxidation process has been found to contain strong acids that create significant physical damages to the tube chirality, helicity, and micropathway of CNTs. These damages severely degrade the originally desirable properties of CNTs [20-26]. The dry oxidation process using ozone in the presence of ultraviolet ozonolysis $\left(\mathrm{UV} / \mathrm{O}_{3}\right)$ has been an alternative treatment to issues associated with wet oxidation [27-30].

This study mainly aims to investigate the effect of functionalized MWCNTs on the electrical and mechanical properties of nanocomposites. Functionalization here refers to the acid and $\mathrm{UV} / \mathrm{O}_{3}$ treatments. The scope of this study is then followed by the fabrication of multifiller polymer nanocomposites to achieve good electrical and mechanical properties that had been set by the US Department of Energy targets as shown in Table 1 [31]. Lastly, the comparative study between the acid- and $\mathrm{UV} / \mathrm{O}_{3}$-treated oxidation treatments on the hybrid MWCNTs composites is discussed.

\section{Experimental}

2.1. Materials. MWCNTs were used as nanofillers in this study. NC 7000 was purchased from Nanocyl, Belgium. Its diameter and length were $9.5 \mathrm{~nm}$ and $1.5 \mu \mathrm{m}$, respectively, with purity of $\geq 90 \%$, as reported by the manufacturer.

The synthetic $G$ powder used in this study had an electrical resistivity of $0.03 \Omega \mathrm{cm}$, a surface ratio of $1.5 \mathrm{~m}^{2} \mathrm{~g}^{-1}$, and an average particle size of $44 \mu \mathrm{m}$. The $\mathrm{G}$ powder was purchased from a local agent of Asbury Carbons, New Jersey. The epoxy resin (EP) used in this research was bisphenol-Abased epoxy resin (635), with a viscosity of 6 poise obtained from US Composites, Inc. A lower viscosity of the epoxy matrix was selected to obtain better wetting conditions with reinforcement fillers.

2.2. Preparation of MWCNTs. Two different functionalization treatments were done in this study, namely, the wellestablished acid-treated oxidation and the latest $\mathrm{UV} / \mathrm{O}_{3}$ treated oxidation. MWCNTs were treated with sulfuric and nitric acids at $3: 1(\mathrm{v} / \mathrm{v})$ ratio to produce a high-concentration acid solution. The MWCNTs were suspended in a dilute solution and refluxed under a given set of oxidation conditions. The oxidized MWNTs were subsequently filtered and washed with distilled water until they reached $\mathrm{pH}$ 7. The functionalized MWCNTs were dried in an oven at $40^{\circ} \mathrm{C}$ for $48 \mathrm{~h}$. For $\mathrm{UV} / \mathrm{O}_{3}$-treated functionalization, the MWCNTs were
TABLE 1: US Department of Energy targets of a bipolar plate.

\begin{tabular}{lc}
\hline Property & Value \\
\hline Electrical conductivity & $>100 \mathrm{~S} \mathrm{~cm}^{-1}$ \\
Thermal conductivity & $>10 \mathrm{~W}(\mathrm{mK})^{-1}$ \\
Flexural strength & $>25 \mathrm{MPa}$ \\
Corrosion resistance & $<1 \mu \mathrm{A} \mathrm{cm}^{-2}$ \\
Weight & $<0.4 \mathrm{~kg} \mathrm{~kW}^{-1}$ \\
Gas permeability & $<2 \times 10^{-6} \mathrm{~cm}^{3} \mathrm{~cm}^{-2} \mathrm{~s}^{-1}$ at $80^{\circ} \mathrm{C}$ and $3 \mathrm{~atm}$ \\
\hline
\end{tabular}

exposed to a self-made in-house $\mathrm{UV} / \mathrm{O}_{3}$ system for $95 \mathrm{~min}$ exposure time at $18 \mathrm{~cm}$ exposure distance and $10 \mathrm{Lmg}^{-1}$ ozone flow rate. These parameters were set according to the pilot and optimization experiments using the response surface method (RSM) technique in earlier studies.

2.3. Preparation of Composites. For the fabrication of singlefiller EP/MWCNT nanocomposites, the epoxy and curing agent were mixed at $3: 1$ ratio in wt $\%$. The mixture was mixed using a high-speed mechanical mixer (RW 20-KIKAWERK) at $1200 \mathrm{rpm}$ for $40 \mathrm{~s}$. MWCNTs with different loading concentrations were added into the epoxy and curing agent mixture. The suspension was mixed again at $800 \mathrm{rpm}$ for $3 \mathrm{~min}$. The composite mixture was poured into a steel mold for compression molding at $130^{\circ} \mathrm{C}$ for $1.5 \mathrm{~h}$. On the other hand, the multifiller EP/G/MWCNT nanocomposites were fabricated in three stages. In the first stage, the CNTs (5 wt\%) and $\mathrm{G}(75 \mathrm{wt} \%)$ concentrations were mixed using a planetary ball mill to obtain a homogeneous mixture. The ball-topowder ratio used was $4: 1$, with stainless balls of $10 \mathrm{~mm}$ in diameter and at a rotating speed of $200 \mathrm{rpm}$ for $1 \mathrm{~h}$. In the second stage, the EP and curing agent were mixed using the high-speed mechanical mixer at $1200 \mathrm{rpm}$ for $40 \mathrm{~s}$. Finally, the G/CNTs are mixed further using an internal mixer with a Haake torque rheometer at a temperature of $30^{\circ} \mathrm{C}$. The rotational speed and mixing time were set at $20 \mathrm{rpm}$ and $5 \mathrm{~min}$, respectively. The composite mixtures were poured into a steel mold $(100 \mathrm{~mm} \times 100 \mathrm{~mm} \times 3 \mathrm{~mm})$ at $130^{\circ} \mathrm{C}$ curing temperature. The curing pressure was maintained at $10 \mathrm{MPa}$ for $1.5 \mathrm{~h}$.

\section{Characterization}

3.1. Electrical Conductivity Measurement. The electrical conductivities of the nanocomposites were determined using two different methods, namely, the in- and through-plane conductivities. The in-plane electrical conductivity of the composite was measured using a Jandel Multi Height Four-Point Probe and an RM3 Test Unit, which has a constant-current source and digital voltmeter. This equipment can measure sheet resistance ranging from $1 \mathrm{~m} \Omega \mathrm{cm}^{-1}$ to $5 \times 10^{8} \Omega \mathrm{cm}^{-1}$ and volume resistivity ranging from $10^{-3}$ to $10^{6} \Omega \mathrm{cm}$. Meanwhile, through-plane electrical conductivity was measured using CTU-01 from ZBT GmbH Duisburg.

3.2. Mechanical Property Measurement. Three-point flexural testing was performed using a Universal Testing Machine (Instron 5567). Testing was based on an ASTM D790-03 
standard with a sample dimension of $100 \times 12.7 \times 2.5 \mathrm{~mm}^{3}$ and supported range distance of $50.0 \mathrm{~mm}$. The hardness of composites was performed using a dynamic ultramicrohardness tester using a Vickers-type diamond indenter. Dwell load is $0.98 \mathrm{~N}$ and dwell time is $10 \mathrm{sec}$ which were used as test parameters.

3.3. Fracture Surface Morphology. The fractured surfaces of nanocomposites were observed using a field emission scanning electron microscope (SUPRA 55VPSEM) to study the dispersion and intercalation mechanisms of conductive fillers in the polymer matrix.

\section{Results and Discussion}

\subsection{Single Filler}

4.1.1. In-Plane Electrical Conductivity. The in-plane electrical conductivity of polymer composites depends on the arrangement of reinforcement materials and the dispersion and distribution of the reinforcing materials in the polymer matrix. The reinforcement materials for CNTs in the composite produced a conductive network that helps the movement of electrons and indirectly becomes a conductive composite. Figure 1 shows the in-plane electrical conductivity of the composites produced using three types of CNTs, namely, the As-produced MWCNTs, acid-treated MWCNTs, and $\mathrm{UV} / \mathrm{O}_{3}$-treated MWCNTs. The in-plane electrical conductivity of all treatments of MWCNTs/epoxy nanocomposites, with the addition of a small amount of MWCNTs, increased with the increasing weight loading of the reinforcing material composition, the CNTs [32-35]. A comparison between the three types of composites shows that the composites with As-produced MWCNTs achieved the highest in-plane electrical conductivity of $2.84 \mathrm{~S} \mathrm{~cm}^{-1}$, whereas the composites with $\mathrm{UV} / \mathrm{O}_{3}$ - and acid-treated MWCNTs gave electrical conductivity values of 2.2 and $1.1 \mathrm{~S} \mathrm{~cm}^{-1}$, respectively. The composite with acid-treated MWCNTs showed the lowest inplane electrical conductivity at a weight percentage loading composition of $10 \mathrm{wt} \%$ MWCNTs. This phenomenon is due to the treatment of strong acids during wet oxidation, which causes structural damage to the wall of MWCNTs and hence reduces the overall electrical conductivity of MWCNTs $[20,21,33]$. However, the composite with $\mathrm{UV} / \mathrm{O}_{3}$-treated MWCNTs showed an upward trend after the composition of $10 \mathrm{wt} \%$. Even though it shows increasing trend for all types of CNTs, addition CNTs more than $10 \mathrm{wt} \%$ caused improper mixing process occurred, epoxy as a matrix not properly wetted with the conductive fillers due to high surface area of CNTs. Moreover compression molded plate at more than $10 \mathrm{wt} \%$ MWCNTs has significant voids which are not suitable for bipolar plate application.

4.1.2. Mechanical Test. The hardness properties of EP/ MWCNT composites are shown in Figure 2. The test was performed for MWCNT loadings of $0 \mathrm{wt} \%, 2.5 \mathrm{wt} \%, 5.0 \mathrm{wt} \%$, $7.5 \mathrm{wt} \%$, and $10 \mathrm{wt} \%$ for the three types of treatments, namely, the As-produced, acid-treated, and $\mathrm{UV} / \mathrm{O}_{3}$-treated MWCNTs. The hardness of pure epoxy is increased with additional

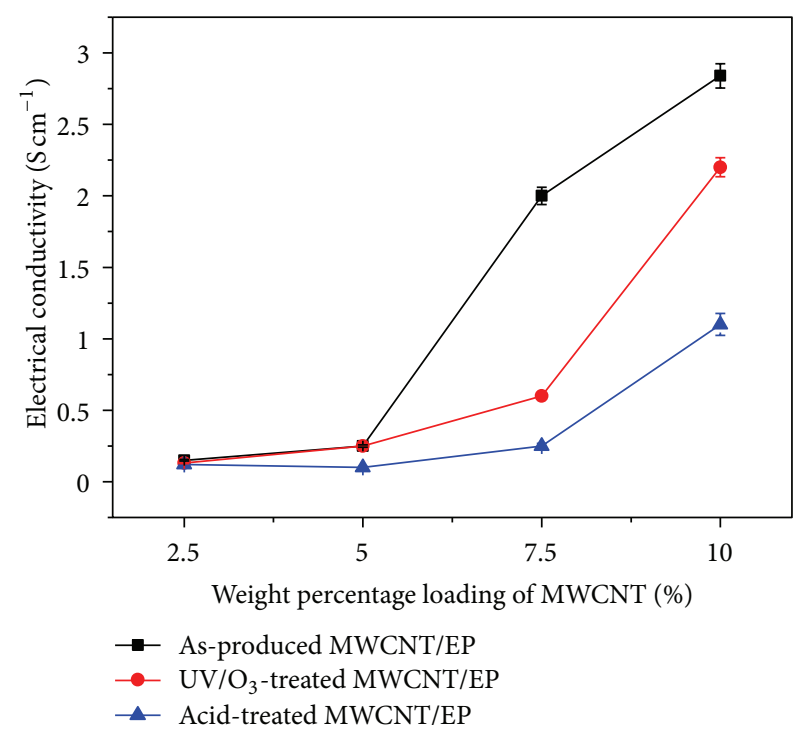

FIGURE 1: In-plane electrical properties of As-produced, acidtreated, and $\mathrm{UV} / \mathrm{O}_{3}$-treated MWCNT composites.

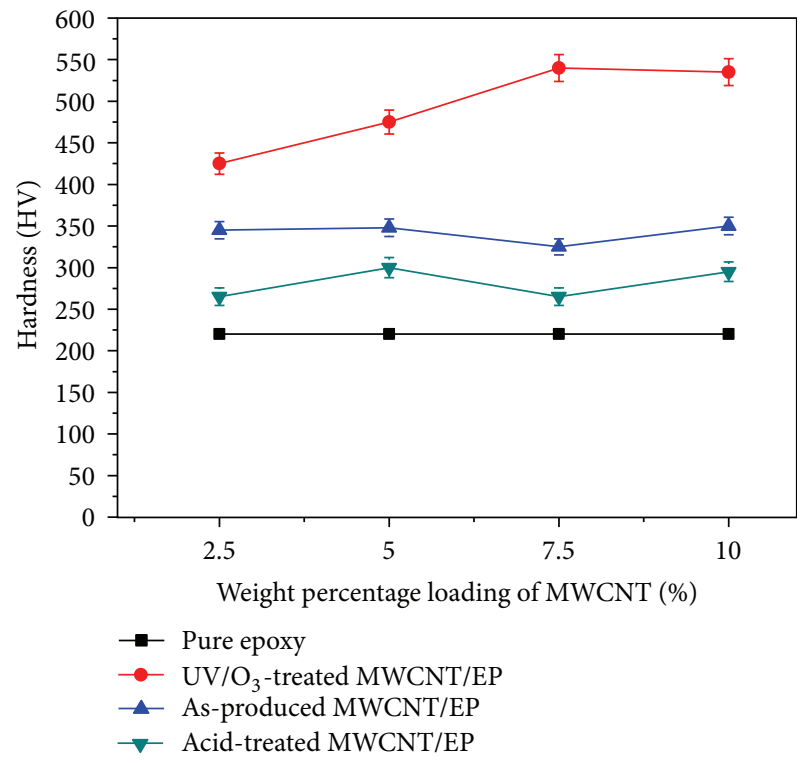

FIGURE 2: Mechanical properties of As-produced, $\mathrm{UV} / \mathrm{O}_{3}$-treated, and acid-treated MWCNTs compared with pure epoxy.

of MWCNTs in polymer matrix. Figure 2 shows that $\mathrm{UV} / \mathrm{O}_{3}$ treated MWCNTs exhibited the highest hardness, follows by As-produced and acid-treated MWCNTs/EP composites. This finding supports the results of previous studies that $\mathrm{UV} / \mathrm{O}_{3}$ treatment gives better mechanical properties than acid treatment because of the defect formed on the surface of MWCNTs during acid treatments [20, 22-26]. The hardness of the $\mathrm{UV} / \mathrm{O}_{3}$-treated MWCNTs is increasing until $7.5 \mathrm{wt} \%$ of CNTs and then becomes stable until $10 \mathrm{wt} \%$. However, acid-treated MWCNTs and as-produced MWCNTs/EP show stable manner despite the increase in MWCNTs loading concentration until $10 \mathrm{wt} \%$. 


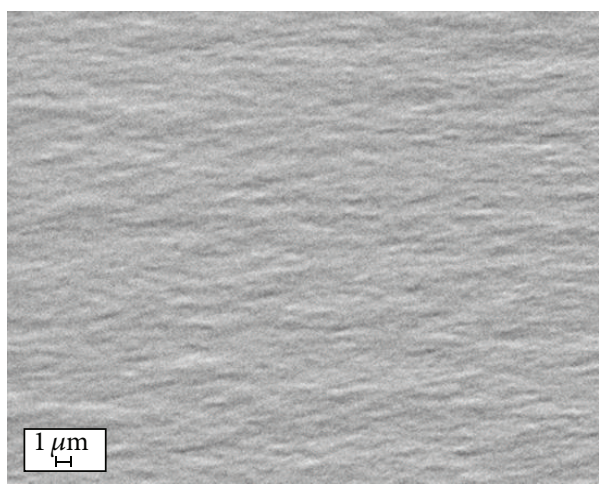

(a)

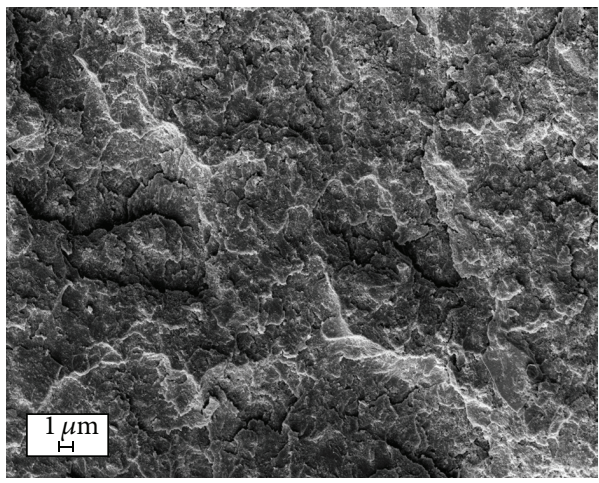

(c)

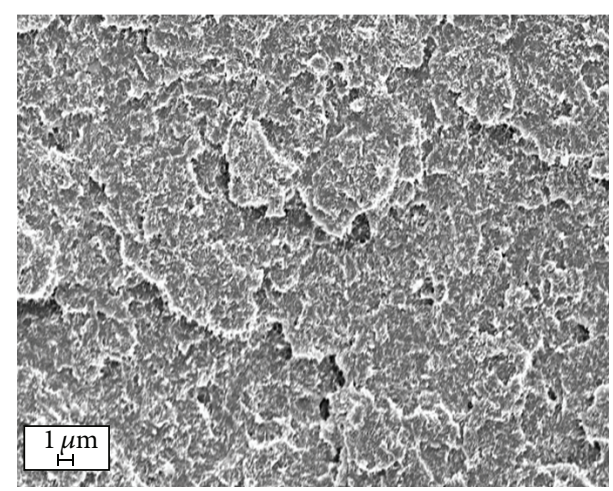

(b)

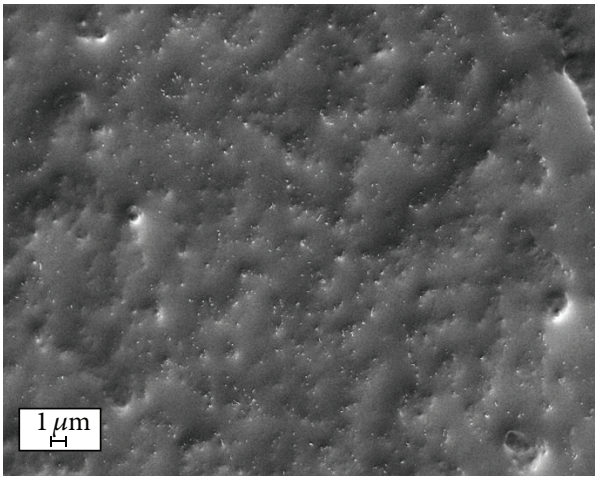

(d)

FIGURE 3: Fracture surface morphology of (a) pure epoxy, (b) As-produced MWCNTs, (c) acid-treated MWCNTs, and (d) UV/O 3 -treated MWCNT/epoxy composites under FE-SEM.

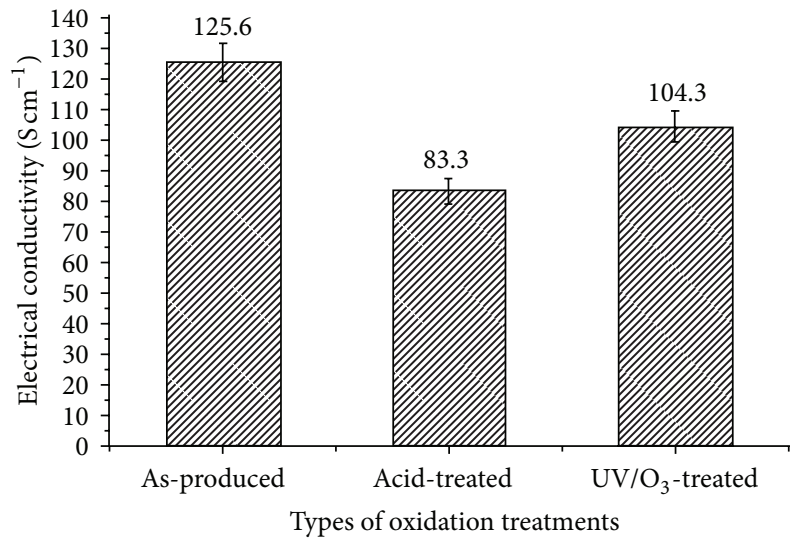

FIGURE 4: In-plane electrical conductivity of EP/G/MWCNTs.

4.1.3. Surface Fracture Morphology. The scanning electron micrographs of the pure epoxy and MWCNT/epoxy nanocomposites for the three types of treatments are shown in Figure 3. The composition was fixed to a weight loading of $10 \mathrm{wt} \%$. The MWCNTs were reasonably well dispersed and evenly distributed over the whole area. Moreover, the $\mathrm{UV} / \mathrm{O}_{3}$-treated MWCNTs seemed shorter in length due to being firmly embedded in polymer matrix. This indicates good adhesion between filler and polymer matrix. Higher

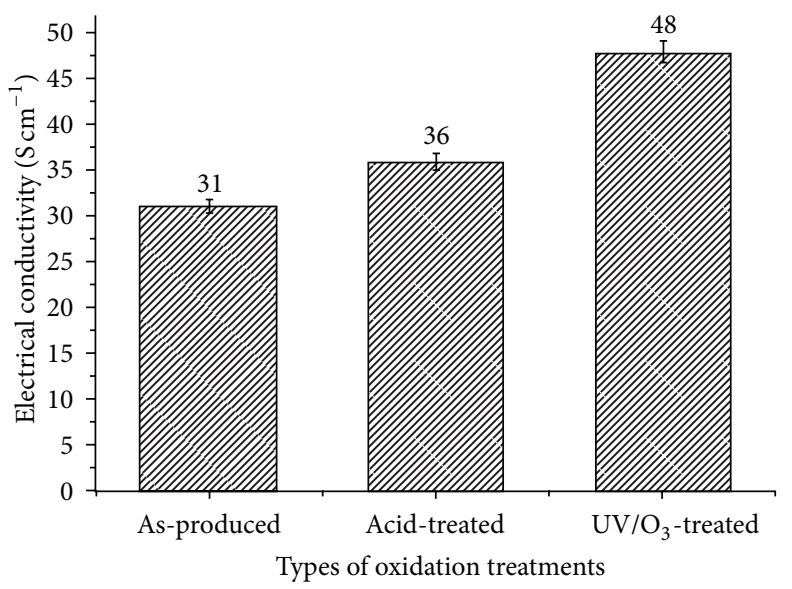

FIgURE 5: Through-plane electrical conductivity of EP/G/ MWCNTs.

amounts of MWCNTs loading concentration in polymer matrix MWCNT content resulted in more networks and increased the in-plane electrical conductivity properties. Compared with chemical functionalization, $\mathrm{UV} / \mathrm{O}_{3}$ treatment showed better dispersion and even better distribution than pure acid treatment [33]. For electrical conductivity behavior, at high electrical conductive polymer composite 


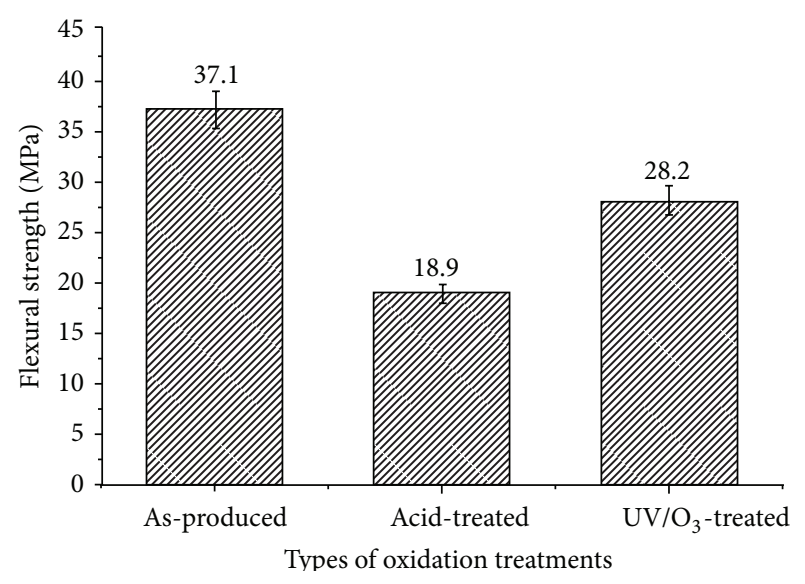

Figure 6: Flexural strength of EP/G/MWCNTs.

where more than $20 \mathrm{~S} \mathrm{~cm}^{-1}$ is required, distribution of MWCNTS with continuous electrical conductive network through matrix composite plays a main role rather than dispersion of MWCNTs without continuous electrical conductive network [8]. Thus, in-plane conductivity results in Figure 3 which is in parallel with this behavior [8].

In this single-filler study, we could not achieve the DOE target for the bipolar plate application [31]. Therefore, further studies on the multifiller or hybrid conductive composite plates were made. A combination of G and CNTs was said to have synergistic effects that could obtain desired in- and through-plane conductivities $[6,12,13]$. The effect of acidand $\mathrm{UV} / \mathrm{O}_{3}$-treated MWCNTs was also discussed in this study.

\subsection{Multifiller}

\subsubsection{Electrical Conductivity}

In-Plane Electrical Conductivity. Based on previous results reported by Suherman et al. which study effect of different combination concentration of MWCNTs and graphite in epoxy matrix. Their findings found that the highest values of in-plane electrical conductivity and throughplane conductivity for multifillers composite plates were at $5 \mathrm{wt} . \%$ of As-produced MWCNTs and $75 \mathrm{wt} \%$ graphite in epoxy matrix [13]. Therefore, this study used composition of EP/G/MWCNTs at (20/75/5) wt.\% with different type of MWCNTs treatment. The in-plane electrical conductivity of the EP/G/MWCNTs nanocomposites for the three types of MWCNT treatments is shown in Figure 4. The hybrid composite plates with As-produced, acid-treated, and $\mathrm{UV} / \mathrm{O}_{3}$-treated MWCNTs showed electrical conductivity values of $125.6,83.3$, and $104.3 \mathrm{~S} \mathrm{~cm}^{-1}$, respectively. The inplane electrical conductivity of the EP/G composite at a composition of (20/80) wt.\% was reported as $50 \mathrm{~S} \mathrm{~cm}^{-1}$ [13]. Thus it indicates that additional CNTs are able to improve electrical conductivity of EP/G composites. The addition of MWCNTsto these hybrid composites increased the electrical conductivity properties to values higher than those of single-filler reinforcement composites. The spaces between the $\mathrm{G}$ particles were filled with small-sized MWCNTs. Thus, networks may be formed in the EP/G/MWCNT composites. However, the type of MWCNT plays an important role in the formation of a conductive network. In this context, this study shows the effect of chemical functionalization on electrical conductivity. The present results clearly show that acidtreated MWCNT composites have low electrical conductivity. The oxidation process using strong acid damages the chirality of the tube, helicity, and micro-CNT flow because of the defects formed during the acid treatment on the CNT surfaces [20-26]. The hybrid composite plate with $\mathrm{UV} / \mathrm{O}_{3}-$ treated and As-produced MWCNTs achieved the electrical conductivity target set by the US DOE for bipolar plates in fuel cells. However, the $\mathrm{UV} / \mathrm{O}_{3}$-treated MWCNTs obtained an electrical conductivity value of $\sim 17 \%$ less than that of the As-produced MWCNTs.

Through-Plane Electrical Conductivity. Figure 5 shows the results obtained by through-plane electrical conductivity. The hybrid composite plates with As-produced, acid-treated, and $\mathrm{UV} / \mathrm{O}_{3}$-treated MWCNTs showed conductivity values of 31,36 , and $48 \mathrm{~S} \mathrm{~cm}^{-1}$, respectively. The through-plane electrical conductivity for the conductive composite polymer was much lower than the in-plane electrical conductivity. This difference was caused by the orientation of $G$ particles in the composite, that is, perpendicular to the compression direction. Therefore, only a small amount of electrical conductivity path flow formed and lowered the through-plane electrical conductivity [36].

4.2.2. Mechanical Test. Good mechanical properties are required for composite materials used in PEMFC bipolar plates. A bipolar plate is required to support thin membranes and electrodes and withstand high clamping forces for the stack assembly. Obtaining high electrical conductivity and sufficient mechanical strength simultaneously from the same material is difficult [6]. In this study, three types of samples were prepared using As-produced, acid-treated, and $\mathrm{UV} / \mathrm{O}_{3}$ treated MWCNTs. Figure 6 shows the flexural strengths of these three types of samples. The flexural strength of the EP/G/As-produced MWCNT composite plate was highest at $37 \mathrm{MPa}$, followed by the $\mathrm{EP} / \mathrm{G} / \mathrm{UV} / \mathrm{O}_{3}$-treated MWCNT composite plate at $28 \mathrm{MPa}$ and, finally, the EP/G/acid-treated MWCNT composite plate at $19 \mathrm{MPa}$. The average ratio and high strength of the CNTs, their dispersion, and the good interfacial bonding between CNTs and the polymer matrix contributed to the increase in the flexural properties of the composite produced. In addition, the $75 \mathrm{wt} \% \mathrm{G}$ content in the composite also contributed to the flexural strength. Therefore, the strength of the EP/G/As-produced MWCNT composite plate reached the DOE target. The $\mathrm{EP} / \mathrm{G} / \mathrm{UV} / \mathrm{O}_{3}$ treated MWCNT plate also reached the minimum value set by the US DOE. However, the acid-treated MWCNT composites gave the lowest value and, therefore, did not reach the minimum target value. These results indicate that $\mathrm{UV} / \mathrm{O}_{3}$ treatment provided better mechanical properties than acid treatment. 


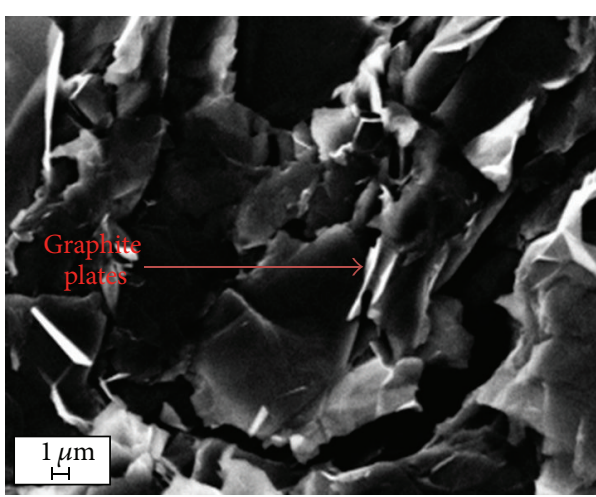

(a)

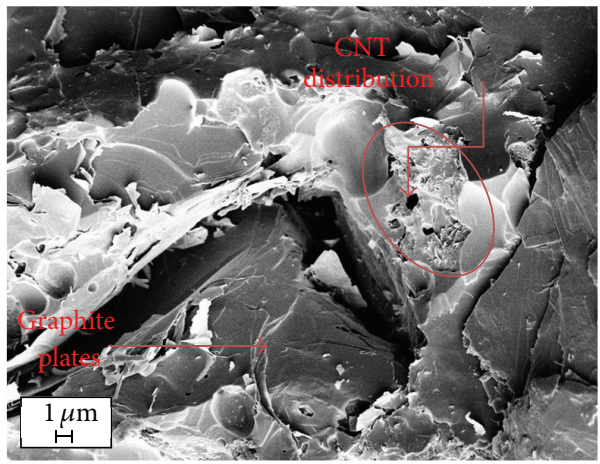

(c)

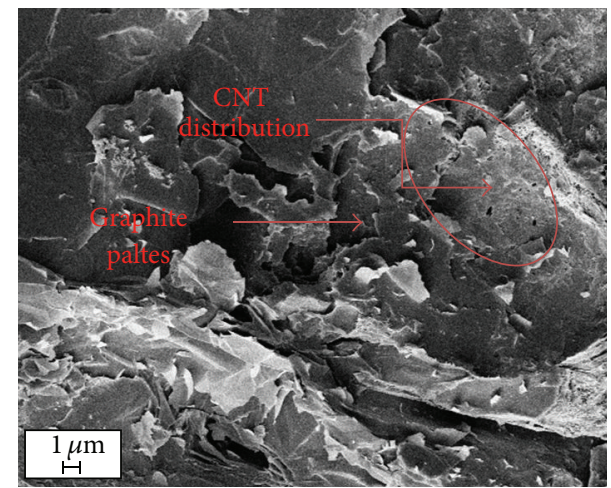

(b)

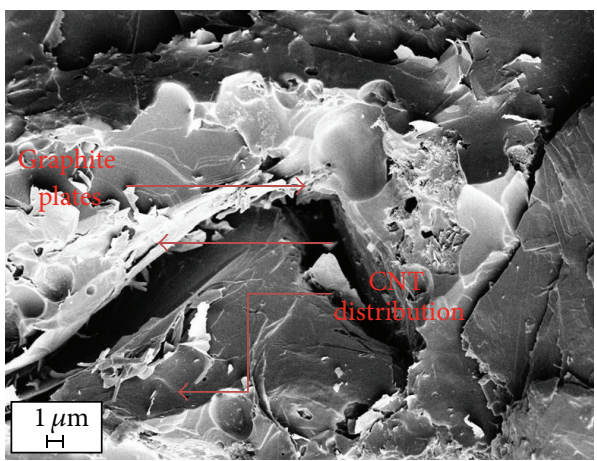

(d)

Figure 7: Surface fracture of (a) EP/G composite, (b) EP/G/As Produced MWCNTs, (c) EP/G/Acid-treated MWCNTs, (d) EP/G/UV/O 3 Treated MWCNTs.

4.2.3. Surface Fracture Morphology. The CNT powder was measured by examining the distribution of CNTs in the composite powder using a scanning electron microscope (FE-SEM). G can be seen in the form of large gray flakes, whereas the MWCNT powder looks like light capillaries (white) because of the gold coating process. The MWCNTs were small; hence, they could fill the voids between the pieces of $\mathrm{G}$ and form a network of conductivity in the composite plate. From Figure 7, the MWCNT distributions in the three types of treatments were good and even. Moreover, the Asproduced MWCNT composite plates obtained better electrical conductivity and mechanical properties compared with the functionalized MWCNTs. The comparison among the treatment processes showed that $\mathrm{UV} / \mathrm{O}_{3}$-treated MWCNTs are more efficient than acid-treated MWCNTs.

\section{Conclusion}

The study showed that $\mathrm{UV} / \mathrm{O}_{3}$-treated MWCNTs have higher electrical conductivity and better mechanical properties than acid-treated MWCNTs for single-filler epoxy nanocomposites. However, highly conductive epoxy composites may be developed using synergistic combinations of $\mathrm{G}$ and CNTs and not single-filler CNTs for bipolar plate applications. The EP/G/As-produced MWCNTs had higher in-plane electrical conductivity than functionalized MWCNTs. However, the
$\mathrm{EP} / \mathrm{G} / \mathrm{UV} / \mathrm{O}_{3}$-treated MWCNTs had the highest throughplane conductivity. Therefore, dry oxidation treatment can be an alternative functionalization method for improving the dispersion and distribution of nanomaterials in a polymer matrix to achieve high electrical conductivity and good mechanical strength simultaneously.

\section{Conflict of Interests}

There is no conflict of interests between the authors and material suppliers mention in this paper (Nanocyl, Asbury Carbon, and US Composites, Inc).

\section{Acknowledgments}

The authors would like to thank the Fuel Cell Institute and the Department of Mechanical and Materials Engineering, Faculty of Engineering and Built Environment, The National University of Malaysia, for the support under Arus Perdana Grant UKM-AP-TK-05-2009.

\section{References}

[1] H. Tawfik, Y. Hung, and D. Mahajan, "Metal bipolar plates for PEM fuel cell-a review," Journal of Power Sources, vol. 163, no. 2, pp. 755-767, 2007. 
[2] A. M. Lafront, E. Ghali, and A. T. Morales, "Corrosion behavior of two bipolar plate materials in simulated PEMFC environment by electrochemical noise technique," Electrochimica Acta, vol. 52, no. 15, pp. 5076-5085, 2007.

[3] J. Huang, D. G. Baird, and J. E. McGrath, "Development of fuel cell bipolar plates from graphite filled wet-lay thermoplastic composite materials," Journal of Power Sources, vol. 150, no. 12, pp. 110-119, 2005.

[4] X. Li and I. Sabir, "Review of bipolar plates in PEM fuel cells: flow-field designs," International Journal of Hydrogen Energy, vol. 30, no. 4, pp. 359-371, 2005.

[5] B. Cunningham and D. G. Baird, "The development of economical bipolarplates for fuel cells," Journal of Materials Chemistry, vol. 16, pp. 4358-4388, 2006.

[6] L. Du and S. C. Jana, "Highly conductive epoxy/graphite composites for bipolar plates in proton exchange membrane fuel cells," Journal of Power Sources, vol. 172, no. 2, pp. 734-741, 2007.

[7] C. Y. Yen, S. H. Liao, Y. F. Lin, C. H. Hung, Y. Y. Lin, and C. C. M. Ma, "Preparation and properties of high performance nanocomposite bipolar plate for fuel cell," Journal of Power Sources, vol. 162, no. 1, pp. 309-315, 2006.

[8] R. Dweiri and J. Sahari, "Microstructural image analysis and structure-electrical conductivity relationship of single- and multiple-filler conductive composites," Composites Science and Technology, vol. 68, no. 7-8, pp. 1679-1687, 2008.

[9] R. Dweiri and J. Sahari, "Electrical properties of carbonbased polypropylene composites for bipolar plates in polymer electrolyte membrane fuel cell (PEMFC)," Journal of Power Sources, vol. 171, no. 2, pp. 424-432, 2007.

[10] J. K. Kuo and C. K. Chen, "A novel Nylon-6-S316L fiber compound material for injection molded PEM fuel cell bipolar plates," Journal of Power Sources, vol. 162, no. 1, pp. 207-214, 2006.

[11] J. Scholta, B. Rohland, V. Trapp, and U. Focken, "Investigations on novel low-cost graphite composite bipolar plates," Journal of Power Sources, vol. 84, no. 2, pp. 231-234, 1999.

[12] H. Suhermana, A. B. Sulonga, and J. Saharia, "Effect of filler loading concentration, curing temperature and molding pressure on the electrical conductivity of CNTS/graphite/epoxy nanocomposites at high loading of conductive fillers," International Journal of Mechanical and Materials Engineering, vol. 5, no. 1, pp. 74-79, 2010.

[13] H. Suherman, A. B. Sulong, and J. Sahari, "Effect of the compression molding parameters on the in-plane and through-plane conductivity of carbon nanotubes/graphite/epoxy nanocomposites as bipolar plate material for a polymer electrolyte membrane fuel cell," Ceramics International, vol. 39, no. 2, pp. 1227-1284, 2013.

[14] S. Iijima, "Helical microtubules of graphitic carbon," Nature, vol. 354, no. 6348, pp. 56-58, 1991.

[15] Y. Ando, X. Zhao, H. Shimoyama, G. Sakai, and K. Kaneto, "Physical properties of multiwalled carbon nanotubes," International Journal of Inorganic Materials, vol. 1, no. 1, pp. 77-82, 1999.

[16] M. Zhang, L. Su, and L. Mao, "Surfactant functionalization of carbon nanotubes (CNTs) for layer-by-layer assembling of CNT multi-layer films and fabrication of gold nanoparticle/CNT nanohybrid," Carbon, vol. 44, no. 2, pp. 276-283, 2006.

[17] A. A. Hirsh, "Functionalization of single-walled carbon nanotubes," Angewandte Chemie, vol. 41, no. 11, pp. 1853-1859, 2002.

[18] Y. J. Kim, T. S. Shin, H. D. Choi, J. H. Kwon, Y. C. Chung, and H. G. Yoon, "Electrical conductivity of chemically modified multiwalled carbonnanotube/epoxy composites," Carbon, vol. 43, no. 1, pp. 23-30, 2005.

[19] A. B. Sulong, N. Muhamad, J. Sahari, R. Ramli, B. M. Deros, and J. Park, "Electrical conductivity behaviour of chemical functionalized MWCNTs epoxy nanocomposites," European Journal of Scientific Research, vol. 29, no. 1, pp. 13-21, 2009.

[20] J. Park and A. B. B. Sulong, "Effect of chemically surface modified MWNTs on the mechanical and electrical properties of epoxy nanocomposites," Studies in Surface Science and Catalysis, vol. 165, pp. 405-408, 2007.

[21] A. B. Sulong, C. H. Azhari, R. Zulkifli, M. R. Othman, and J. Park, "A comparison of defects produced on oxidation of carbon nanotubes by acid and UV ozone treatment," European Journal of Scientific Research, vol. 33, no. 2, pp. 295-304, 2009.

[22] S. D. Kim, J. W. Kim, J. S. Im, Y. H. Kim, and Y. S. Lee, "A comparative study on properties of multi-walled carbon nanotubes (MWCNTs) modified with acids and oxyfluorination," Journal of Fluorine Chemistry, vol. 128, no. 1, pp. 60-64, 2007.

[23] Y. Zhang, Z. Shi, Z. Gu, and S. Iijima, "Structure modification of single-wall carbon nanotubes," Carbon, vol. 38, no. 15, pp. 20552059, 2000.

[24] Y. Wang, J. Wu, and F. Wei, "A treatment method to give separated multi-walled carbon nanotubes with high purity, high crystallization and a large aspect ratio," Carbon, vol. 41, no. 15, pp. 2939-2948, 2003.

[25] C. A. Martin, J. K. W. Sandler, A. H. Windle et al., "Electric fieldinduced aligned multi-wall carbon nanotube networks in epoxy composites," Polymer, vol. 46, no. 3, pp. 877-886, 2005.

[26] K. Bubke, H. Gnewuch, M. Hempstead, J. Hammer, and M. L. H. Green, "Optical anisotropy of dispersed carbon nanotubes induced by an electric field," Applied Physics Letters, vol. 71, no. 14, pp. 1906-1908, 1997.

[27] E. Najafi, J. Y. Kim, S. H. Han, and K. Shin, "UV-ozone treatment of multi-walled carbon nanotubes for enhanced organic solvent dispersion," Colloids and Surfaces A, vol. 284-285, pp. 373-378, 2006.

[28] L. Cai, J. L. Bahr, Y. Yao, and J. M. Tour, "Ozonation of singlewalled carbon nanotubes and their assemblies on rigid selfassembled monolayers," Chemistry of Materials, vol. 14, no. 10, pp. 4235-4241, 2002.

[29] M. L. Sham and J. K. Kim, "Surface functionalities of multiwall carbon nanotubes after UV/Ozone and TETA treatments," Carbon, vol. 44, no. 4, pp. 768-777, 2006.

[30] M. Grujicic, G. Cao, A. M. Rao, T. M. Tritt, and S. Nayak, "UVlight enhanced oxidation of carbon nanotubes," Applied Surface Science, vol. 214, no. 1-4, pp. 289-303, 2003.

[31] http://wwwl.eere.energy.gov/hydrogenandfuelcells/mypp/pdfs/ fuel_cells.pdf.

[32] P. C. Ma, M. Y. Liu, H. Zhang et al., "Enhanced electrical conductivity of nanocomposites containing hybrid fillers of carbon nanotubes and carbon black," ACS Applied Materials of Interface, vol. 1, pp. 1090-1096, 2009.

[33] S. Zdenko, T. Dimitrios, S. P. Kon, and G. Contas, "Carbon nanotube-polymer composites: chemistry, processing, mechanical and electrical properties," Progress in Polymer Science, vol. 35, no. 3, pp. 357-401, 2010.

[34] H. Suherman, A. B. Sulong, and J. Sahari, "Eletrical conductivity of the multi-walled carbon nanotubes/epoxy nanocomposites," World Journal of Engineering, vol. 6, p. 987, 2009.

[35] P. Pisitsak, R. Magaraphan, and S. C. Jana, "Electrically conductive compounds of polycarbonate, liquid crstalline polymer, and 
mulltiwalled carbon nanotubes," Journal of Nanomaterials, vol. 2012, Article ID 642080, 10 pages, 2012.

[36] M. C. Hsiao, S. H. Liao, M. Y. Yen et al., "Electrical and thermal conductivities of novel metal mesh hybrid polymer composite bipolar plates for proton exchange membrane fuel cells," Journal of Power Sources, vol. 195, no. 2, pp. 509-515, 2010. 

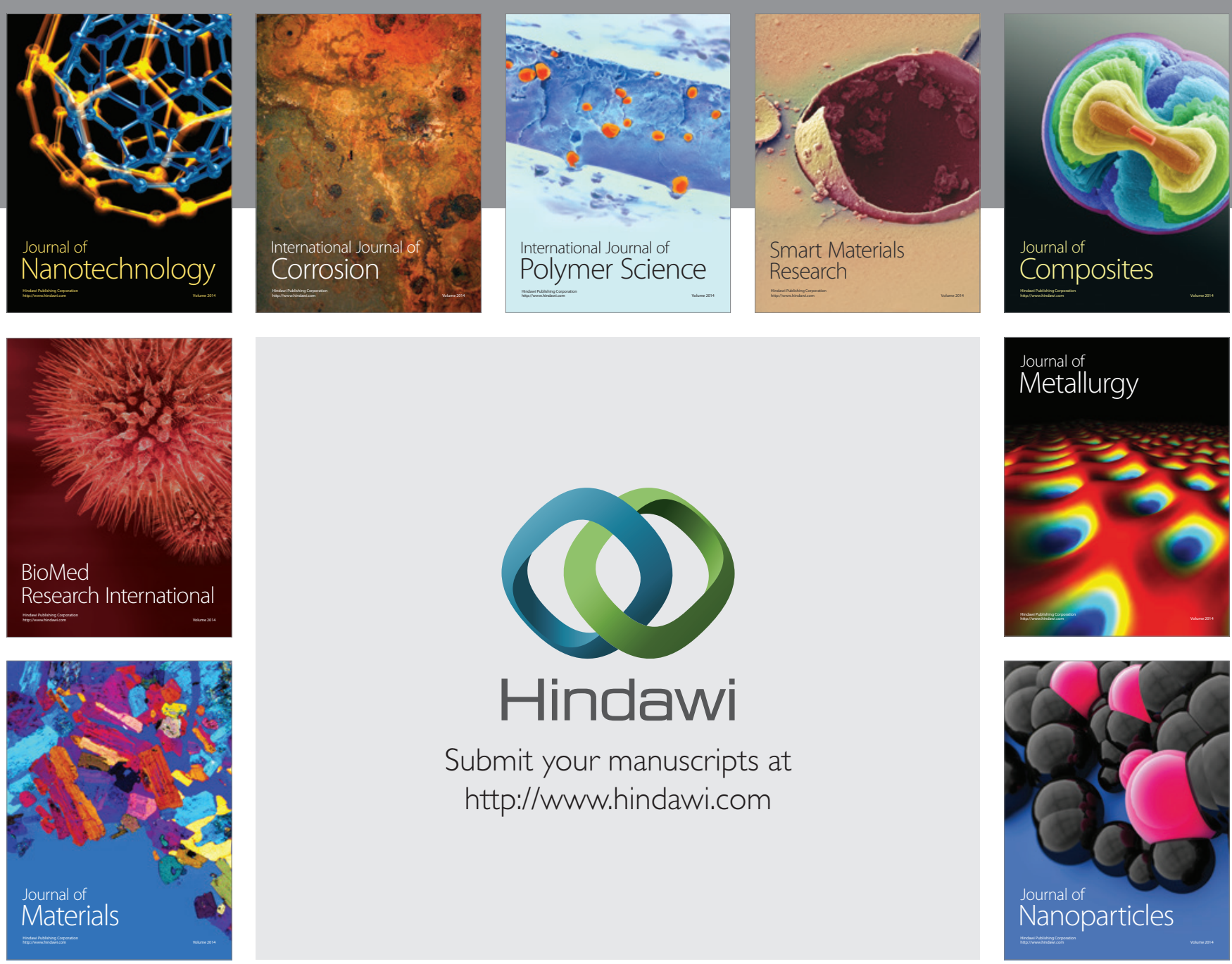

Submit your manuscripts at http://www.hindawi.com
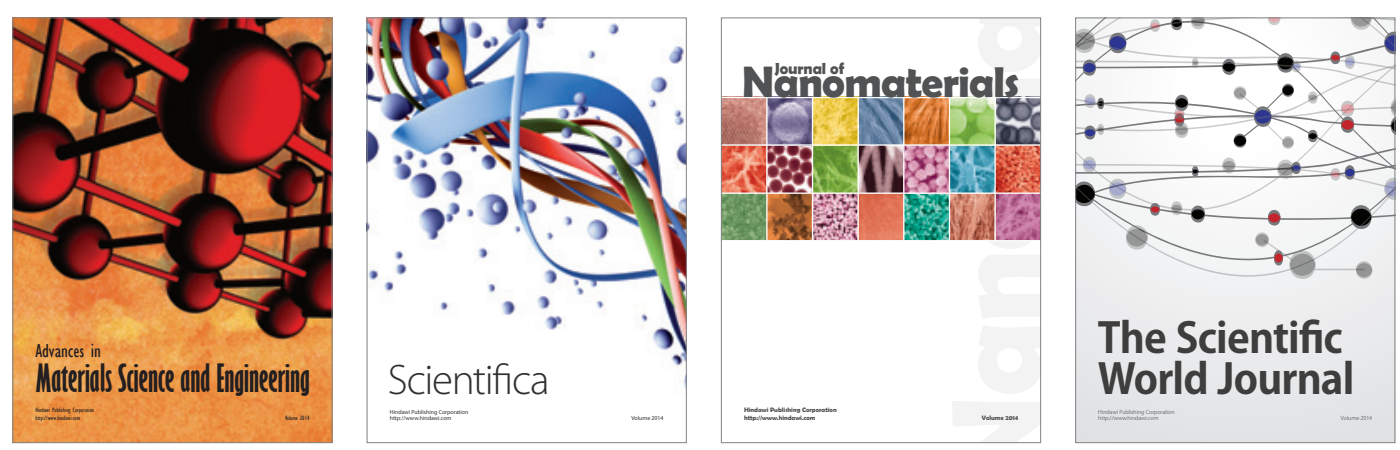

\section{The Scientific World Journal}
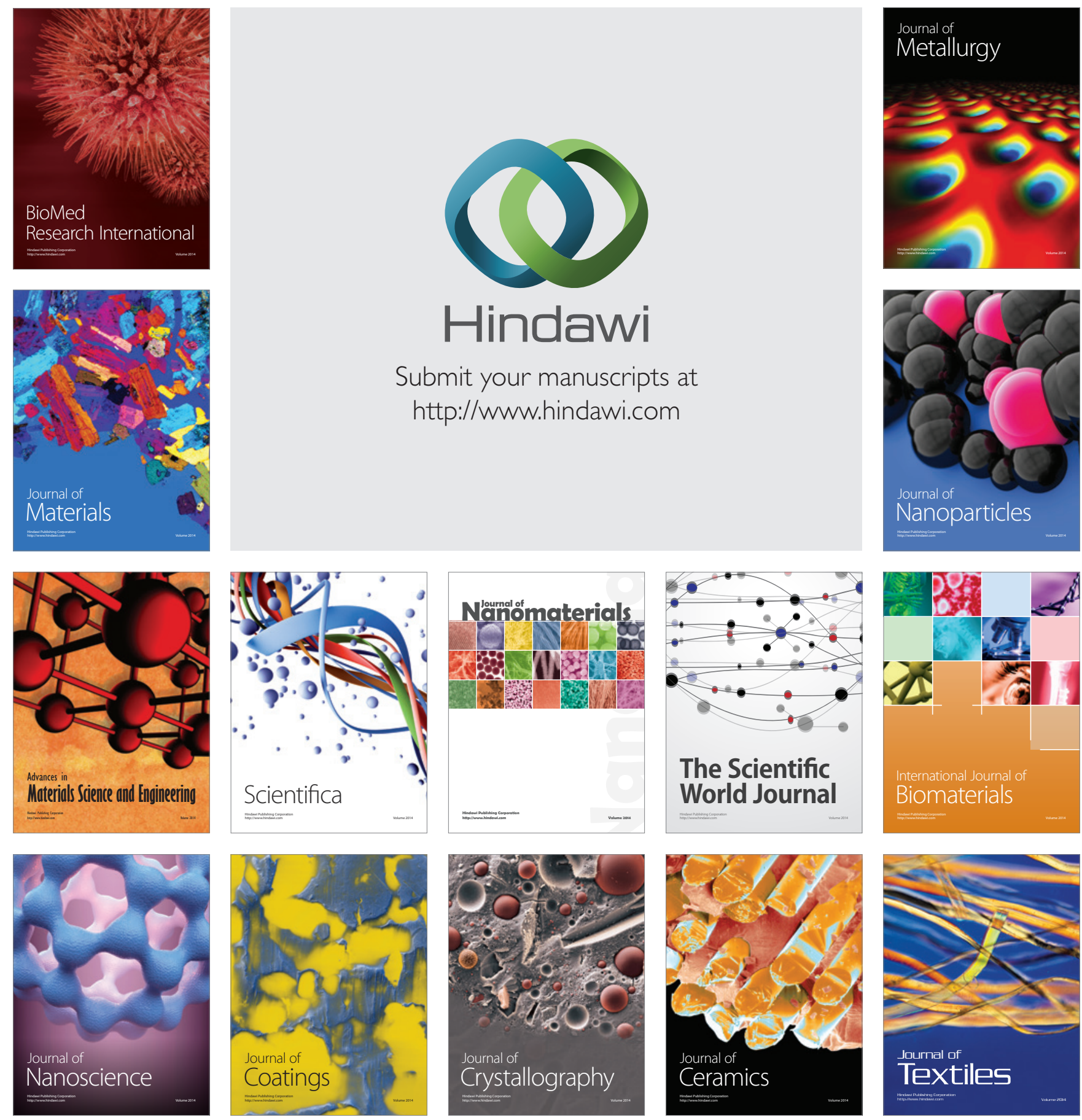